\title{
Bioaccumulation and Non-carcinogenic Health Risk Assessment of Heavy Metals in Selected Fish Species from South Bay of Laguna Lake
}

\author{
Carmela Jhoy G. Mercado, RND, MSc, ${ }^{1}$ Liezl M. Atienza, RND, PhD, ${ }^{2}$ Clarissa B. Juanico, RND, PhD, ${ }^{2}$ \\ Dinah Pura T. Depositario, DBA ${ }^{3}$ and Wilma A. Hurtada, $\mathrm{PhD}^{2}$ \\ ${ }^{1}$ College of Food Nutrition and Dietetics, Laguna State Polytechnic University - Los Baños Campus, Laguna, Philippines \\ ${ }^{2}$ Institute of Human Nutrition and Food, College of Human Ecology, University of the Philippines Los Baños, Laguna, Philippines \\ ${ }^{3}$ College of Economics and Management, University of the Philippines Los Baños, Laguna, Philippines
}

\begin{abstract}
Objective. The study aimed to determine the concentration of three heavy metals namely, lead ( $\mathrm{Pb})$, cadmium (Cd) and chromium $(\mathrm{Cr})$ present in head, stomach and muscle parts of Nile Tilapia (Oreochromis niloticu) and Blackchin Tilapia (Sarotherodon melanotheron) collected from different sampling sites in South Bay area of Laguna Lake and evaluate its potential health risk for adult consumers.

Methods. Live samples of Nile Tilapia and Blackchin Tilapia were hand-collected from three sites of South Bay of Laguna Lake during wet season. Raw and boiled samples were prepared for analysis. Heavy metal concentrations $\left(\mathrm{mg} \mathrm{kg}^{-1}\right)$ were determined through flame atomic absorption spectrophotometry (AAS). The potential health risk posed by more than one metal was calculated using the Total Hazard Quotient (THQ).

Results. The heavy metal detected with the highest concentration was $\mathrm{Pb}$, present in Nile Tilapia. The mean concentrations of $\mathrm{Pb}, \mathrm{Cd}$, and $\mathrm{Cr}$ in both fish samples were high in the head part. Boiled samples have significantly lower concentrations of heavy metal $(p<0.05)$ compared to raw samples. THQ values for $\mathrm{Cd}$ in raw fish samples were higher than the recommended level of exposure (THQ < 1.0).
\end{abstract}

Conclusion. The study revealed that cadmium is of greater concern in terms of possible adverse health effects associated with heavy metal bioaccumulation. However, the presence of other metals may further increase the risk of non-carcinogenic adverse effects. The lower health risk is predicted for boiled fish samples.

Key Words: Health risk, Heavy metals, Total hazard quotient (THQ), Hazard Index (HI), Nile Tilapia, Blackchin Tilapia

\section{INTRODUCTION}

Corresponding author: Carmela Jhoy G. Mercado, RND, MSc College of Food Nutrition and Dietetics

Laguna State Polytechnic University - Los Baños Campus

Los Baños 4030, Laguna Philippines

Email: cjmercado2420@Ispu.edu.ph
Laguna Lake is the largest lake in the Philippines and the second largest in Southeast Asia. The most dominant use of the lake is on fisheries. From 1997 to 2000, the lake yielded approximately 37,000 to 47,000 MT (metric tons) of fish- both from the fish pens and open fisheries. ${ }^{1}$ It has been known as a major source of food and livelihood for people inhabited around it. However, Laguna Lake is besieged daily with anthropogenic pollutants from industrial, domestic and agricultural waste which can be absorbed by aquatic plants and animals. According to Molina (2011; 2015), the Laguna Lake water quality has deteriorated through the years due to various point sources of pollution. ${ }^{2}$ Moreover, industry development and rapid urbanization from the northwestern to the western shores of Laguna 
Lake have led to land-use changes which result in water pollution and ecosystem degradation. ${ }^{3}$

The presence of pollutants causes undesirable changes in an ecosystem. This has both a direct and indirect impact on the ecological balance of the environment and ultimately affects humans. Among these numerous contaminants, heavy metal pollution in coastal regions has become a global threat because of its toxicity. ${ }^{4}$ As a result, aquatic organisms become exposed to elevated levels of heavy metals. ${ }^{5,6}$

Eight common heavy metals are arsenic, barium, cadmium, chromium, lead, mercury, selenium, and silver. These are all naturally occurring substances which are often present in the environment at low levels but can be dangerous in larger amounts. ${ }^{7}$

Results of many field studies of metal accumulation in fish living in polluted waters show that considerable amounts of various metals deposit in fish tissues without causing mortality. ${ }^{4}$ Molina (2011) reported that commonly consumed fish products from Laguna lake (i.e. Bangus, Bighead Carp, Dalag, Kanduli, and Tilapia) were contaminated with Cadmium (Cd), Lead (Pb), Mercury ( $\mathrm{Hg}$ ), Arsenic (As), and Chromium $(\mathrm{Cr})$. The results of the study also further revealed that concentrations of heavy metals in fish samples varied from different seasons. There was generally lower heavy metal concentration during wet season compared to dry season. ${ }^{2}$

Humans are generally exposed to heavy metals through ingestion or inhalation. Health Risk Assessment is done to determine the likelihood of harm associated with exposure to the chemical (WHO, 2010). ${ }^{8}$ This study aimed to evaluate the existing levels of heavy metals such as chromium, cadmium, and lead in two edible fish species (i.e., Nile Tilapia and Blackchin Tilapia) collected from South Bay area of Laguna Lake and predict potential health implications of long-term consumption heavy metal-contaminated fish samples.

\section{MATERIALS AND METHODS}

\section{Sample collection}

Three coastal areas adjacent to towns around the South Bay area of Laguna Lake (i.e., Calamba, Los Baños and Bay, Laguna) were chosen as collection sites (Figure 1). Live samples of Nile Tilapia (Oreochromis niloticu) and Blackchin Tilapia (Sarotherodon melanotheron) were hand-collected from each site with the help of professional local fishermen during the wet season (June 2017). All samples were placed into dark plastic bags containing the ambient water and transported to the laboratory in an iced chest. Three edible parts (i.e. head, stomach, and muscle tissue) of both Nile and Blackchin Tilapia were separated for individual analysis. Two sets of samples were prepared, one of which was raw while the other was boiled. All pooled samples were analyzed for $\mathrm{Pb}, \mathrm{Cd}$ and $\mathrm{Cr}$ concentration.

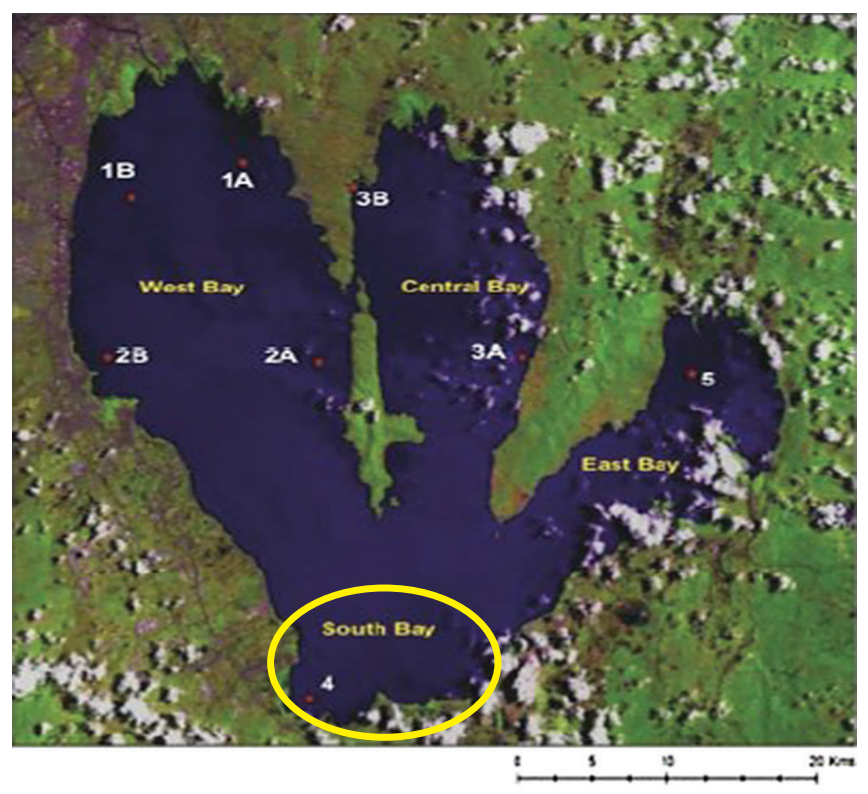

Figure 1. Sample Location (Source: Molina, 2014).

\section{Heavy Metal Concentration Analysis}

The samples (both raw and boiled) were homogenized before wet digestion using Nitric-perchloric acid digestion (Figure 2), following the procedure recommended by the AOAC (1990). . ${ }^{9}$ Boiled samples were cooked using distilled water for 10 minutes. Five grams of sample was placed in a $250 \mathrm{~mL}$ digestion tube and $15 \mathrm{~mL}$ of concentrated Nitric acid $\left(\mathrm{HNO}_{3}\right)$ was added. The mixture was heated gently for 30-45 min to oxidize all easily oxidizable matter. After cooling, $5 \mathrm{~mL}$ of $70 \%$ perchloric acid $\left(\mathrm{HClO}_{4}\right)$ was added to the mixture then heated gently until dense white fumes appeared. After cooling, $20 \mathrm{~mL}$ of distilled water was added, and the mixture was heated further to release any fumes. The solution was cooled and filtered through Whatman No. 42 filter paper. Total heavy metal concentration (in $\mathrm{mg} \mathrm{kg}^{-1}$ ) was determined by flame atomic absorption spectrometry (SPAA3000 SPECTRUM Instrument) fueled with air acetylene using $217 \mathrm{~nm}$ spectral wavelength. The detection limit for $[\mathrm{Pb}],[\mathrm{Cd}]$ and $[\mathrm{Cr}]$ were determined at $0.004,0.002$ and $0.001 \mathrm{mg}$ per liter respectively. All laboratory experiments were performed at Laguna State Polytechnic University-Los Baños Campus, Science Research Laboratory.

\section{Health Risk Assessment}

The estimated daily intake (EDI) of $\mathrm{Pb}, \mathrm{Cd}$, and $\mathrm{Cr}$ in fish samples were estimated using the following equation: ${ }^{10}$

$$
[E D I=I R \times M C / B W]
$$

where, IR is the ingestion rate of the samples $\left(102.74 \mathrm{~g} \mathrm{day}^{-1}\right.$, this is the estimated average daily per capita consumption of fish in the Philippines according to FAO- Fisheries and Aquatic Department), ${ }^{11} \mathrm{MC}$ is the metal concentration 


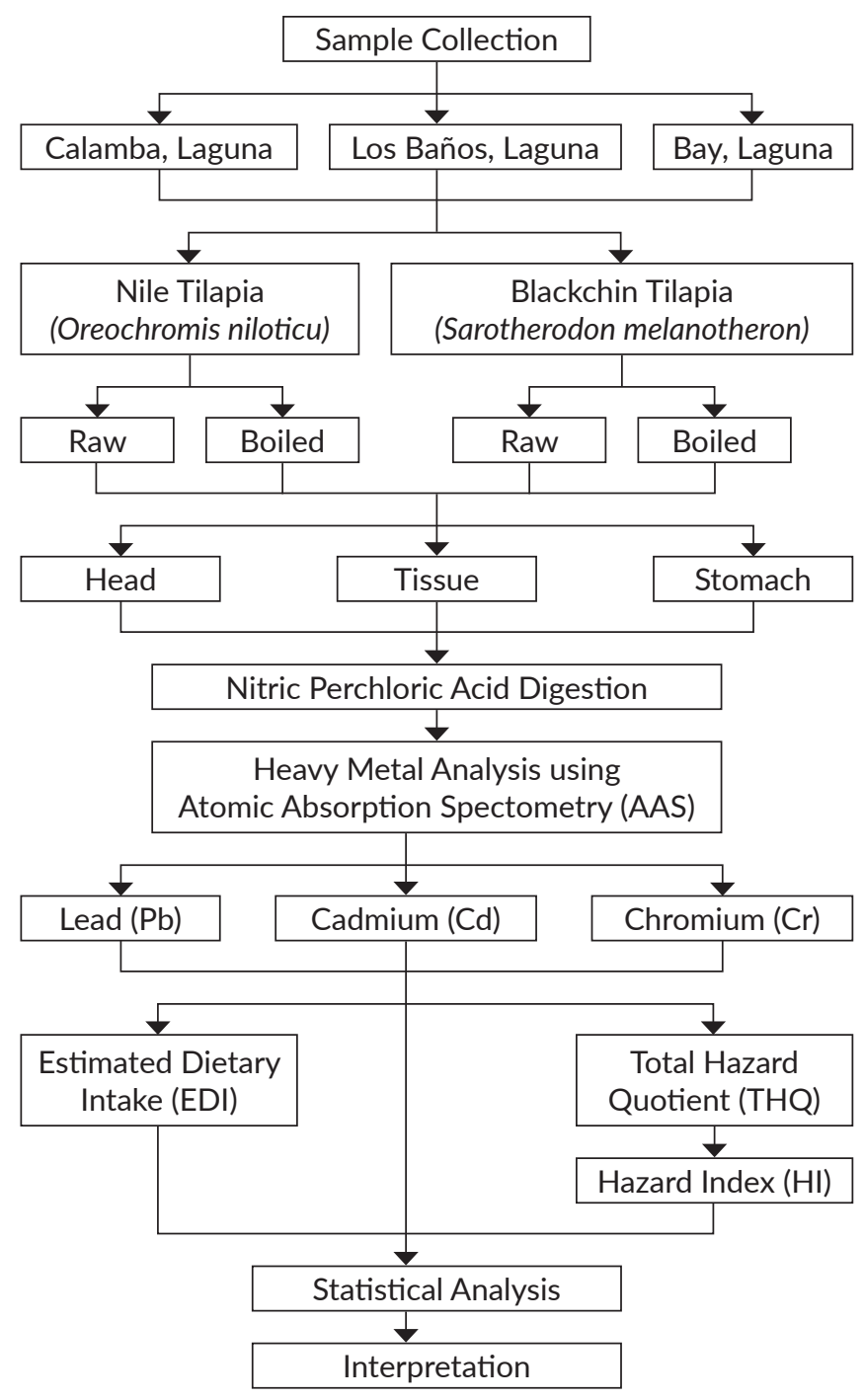

Figure 2. Study Protocol.

of $\mathrm{Cd}, \mathrm{Cr}$, and $\mathrm{Pb}$ in samples (in milligrams per kilogram, fresh weight), and BW is the average human body weight $(52.5 \mathrm{~kg}$ for female and $60.5 \mathrm{~kg}$ for male, according to Philippine Dietary Reference Intake, 2015). ${ }^{12}$ To assess the non-carcinogenic risk due to $\mathrm{Cd}, \mathrm{Cr}$, and $\mathrm{Pb}$ exposure in fish samples, the target hazard quotient (THQ) was computed using the following equation: ${ }^{13}$

$$
\left[T H Q=[(E F r \times E D \times I R \times M C) /(R f D o \times B W \times A T)] \times 10^{-3}\right]
$$

where, EFr is exposure frequency (number of days per year for the average and heavy consumer, assuming 365 days/ year,); $\mathrm{ED}$ is exposure duration (68 years for Filipino) equivalent to the average human lifespan, IR is the ingestion rate of fish $\left(102.74 \mathrm{~g} \mathrm{day}^{-1}\right.$, this is the estimated average daily per capita consumption of fish in the Philippines according to FAO- Fisheries and Aquatic Department, $)^{11}$; $\mathrm{MC}$ is the metal concentration of $\mathrm{Cd}, \mathrm{Cr}$, and $\mathrm{Pb}$ in samples (in milligrams per kilogram, fresh weight); RfDo is the oral reference dose. The applied reference doses according to USEPA (2011) are the following: $0.2 \mathrm{mg} \mathrm{kg}^{-1} \mathrm{day}^{-1}$ for $\mathrm{Pb}$; $0.005 \mathrm{mg} \mathrm{kg}{ }^{-1} \mathrm{day}^{-1}$ for $\mathrm{Cd}$; $0.009 \mathrm{mg} \mathrm{kg}^{-1}$ day $^{-1}$ for $\mathrm{Cr}^{14}{ }^{14} \mathrm{BW}$ is the average human body weight $(52.5 \mathrm{~kg}$ for female and $60.5 \mathrm{~kg}$ for male: ${ }^{12}$ AT is the averaging time for non-carcinogens (assuming 30 years or 10,950 days).

To assess the potential health risk posed by more than one metal, THQ of every metal is summed up and it is known as the Hazard Index (HI). The HI was calculated using the sum of the target hazard quotients of each metal: ${ }^{15}$

$$
\mathrm{HI}=[\mathrm{THQ}] \mathrm{Pb}+[\mathrm{THQ}] \mathrm{Cd}+[\mathrm{THQ}] \mathrm{Cr}
$$

\section{Statistical Analysis}

Mean and standard deviations were used to describe the concentration of $\mathrm{Cd}, \mathrm{Cr}$, and $\mathrm{Pb}$ in the samples. Significant mean differences in heavy metal concentration among samples from different sampling zone and sample parts were tested using two factor ANOVA and pairwise comparison. Statistical tests were performed in SPSS version 20.0 at 95\% confidence level.

\section{RESULTS}

\section{Heavy Metal Concentration in the Three Sampling Sites}

Table 1 shows the heavy metal concentration detected in the different sampling sites. The highest mean $\mathrm{Pb}$ concentration was detected in fish samples collected from Los Baños followed by samples collected from Calamba and Bay respectively. The result also revealed that the mean $[\mathrm{Pb}]$ in the samples from Los Baños $\left(1.546 \pm 0.52 \mathrm{mg} \mathrm{kg}^{-1}\right)$ were significantly different $(\mathrm{p}<0.05)$ from the mean $[\mathrm{Pb}]$ in samples from Calamba $\left(1.199 \pm 0.42 \mathrm{mg} \mathrm{kg}^{-1}\right)$ and Bay $\left(1.065 \pm 0.31 \mathrm{mg} \mathrm{kg}^{-1}\right)$

For [Cd], it was recorded that the highest concentration was present in fish samples collected from Los Baños followed by Calamba and Bay Statistical comparisons indicate that the mean $[\mathrm{Cd}]$ in samples from Los Baños $\left(0.177 \pm 0.09 \mathrm{mg} \mathrm{kg}^{-1}\right)$ was significantly different $(\mathrm{p}<0.05)$ from the mean [Cd] in the fish samples from Calamba $\left(0.119 \pm 0.02 \mathrm{mg} \mathrm{kg}^{-1}\right)$ and Bay $\left(0.093 \pm 0.04 \mathrm{mg} \mathrm{kg}^{-1}\right)$, whereas, the mean [Cd] in the fish samples from Calamba was not significantly different from samples collected from Bay $(\mathrm{P}>0.05)$.

The mean concentration of $\mathrm{Cr}$ was measured highest in fish samples collected from Los Baños $(0.051 \pm 0.02$ $\left.\mathrm{mg} \mathrm{kg}{ }^{-1}\right)$ followed by Calamba $\left(0.042 \pm 0.02 \mathrm{mg} \mathrm{kg}^{-1}\right)$ and Bay $\left(0.039 \pm 0.02 \mathrm{mg} \mathrm{kg}^{-1}\right)$. The statistical comparison indicated that the mean $[\mathrm{Cr}]$ in samples from Los Baños was significantly different from the mean $[\mathrm{Cr}]$ in samples from Bay $(\mathrm{p}<0.05)$. Moreover, no significant differences ( $p>0.05)$ were found between the mean concentration of $\mathrm{Cr}$ in samples from Calamba and mean $[\mathrm{Cr}]$ in samples from Los Baños and Bay. 
Table 1. Mean Heavy Metal concentration (mg kg-1, fresh weight) in fish samples collected from different sites

\begin{tabular}{cccc}
$\begin{array}{c}\text { Sampling } \\
\text { Sites }\end{array}$ & $\begin{array}{c}\text { Lead (Pb) } \\
\text { Mean } \pm \text { SD }\end{array}$ & $\begin{array}{c}\text { Cadmium (Cd) } \\
\text { Mean } \pm \text { SD }\end{array}$ & $\begin{array}{c}\text { Chromium (Cr) } \\
\text { Mean } \pm \text { SD }\end{array}$ \\
Los Baños & $1.546 \pm 0.52^{\mathrm{a}}$ & $0.177 \pm 0.09^{\mathrm{a}}$ & $0.051 \pm 0.02^{\mathrm{a}}$ \\
\hline Calamba & $1.199 \pm 0.42^{\mathrm{b}}$ & $0.119 \pm 0.02^{\mathrm{b}}$ & $0.042 \pm 0.02^{\mathrm{a}, \mathrm{b}}$ \\
\hline Bay & $1.065 \pm 0.31^{\mathrm{b}}$ & $0.093 \pm 0.04^{\mathrm{b}}$ & $0.039 \pm 0.02^{\mathrm{b}}$ \\
\hline
\end{tabular}

Values having the same superscript across a column are not significantly different at $P<0.05$

Table 2. Mean Heavy Metal concentration (mg kg-1, fresh weight) in Nile Tilapia and Blackchin Tilapia

\begin{tabular}{cccc}
$\begin{array}{c}\text { Sampling } \\
\text { Sites }\end{array}$ & $\begin{array}{c}\text { Lead (Pb) } \\
\text { Mean } \pm \text { SD }\end{array}$ & $\begin{array}{c}\text { Cadmium (Cd) } \\
\text { Mean } \pm \text { SD }\end{array}$ & $\begin{array}{c}\text { Chromium }(\mathrm{Cr}) \\
\text { Mean } \pm \text { SD }\end{array}$ \\
\hline Nile Tilapia & $1.1625 \pm 0.58^{\mathrm{a}}$ & $0.47 \pm 0.02^{\mathrm{a}}$ & $0.047 \pm 0.02^{\mathrm{a}}$ \\
\hline $\begin{array}{c}\text { Blackchin } \\
\text { Tilapia }\end{array}$ & $1.3778 \pm 0.29^{\mathrm{a}}$ & $0.155 \pm 0.05^{\mathrm{b}}$ & $0.041 \pm 0.02^{\mathrm{a}}$ \\
\hline
\end{tabular}

Values having the same superscript across a column are not significantly different at $P<0.05$

\section{Bioaccumulation of Heavy Metals in Fish Species}

Table 2 presents the heavy metal accumulation in the two sampled fish species. $\mathrm{Pb}$ bioaccumulation in Blackchin Tilapia was higher than in Nile Tilapia. However, statistical comparison between the mean $[\mathrm{Pb}]$ in Blackchin Tilapia $\left(1.38 \mathrm{mg} \mathrm{kg}^{1}\right)$ was not significantly different $(\mathrm{p}<0.05)$ from the mean $[\mathrm{Pb}]$ in Nile Tilapia $\left(1.16 \mathrm{mg} \mathrm{kg}^{-1}\right)$. The mean $[\mathrm{Cd}]$ was also higher in Blackchin Tilapia $\left(0.155 \pm 0.05 \mathrm{mg} \mathrm{kg}{ }^{1}\right)$ and is significantly different $(\mathrm{p}<0.05)$ from the mean $[\mathrm{Cd}]$ in Nile Tilapia $\left(0.104 \pm 0.08 \mathrm{mg} \mathrm{kg}^{-1}\right)$. Lastly, the mean [Cr] in Blackchin Tilapia $\left(0.041 \pm 0.02 \mathrm{mg} \mathrm{kg}^{-1}\right)$ is lower than the mean $\left[\mathrm{Cr}\right.$ ] in Nile Tilapia $\left(0.047 \pm 0.02 \mathrm{mg} \mathrm{kg}^{-1}\right)$ but the difference was not statistically significant at $\mathrm{p}<0.05$.

Table 3 gives the values of heavy metal concentration in boiled fish compared to raw fish. The statistical comparison revealed that there were significant differences $(p<0.05)$ between the mean concentrations of $\mathrm{Pb}, \mathrm{Cd}$, and $\mathrm{Cr}$ in raw and boiled fish species. In Nile Tilapia, boiling caused approximately $71 \%$ decrease in $[\mathrm{Pb}], 50 \%$ decrease in $[\mathrm{Cd}]$ and $60 \%$ decrease in $[\mathrm{Cr}]$. On the other hand, in Blackchin Tilapia, boiling brought about a $69 \%$ decrease in $[\mathrm{Pb}]$, a $53 \%$ decrease in $[\mathrm{Cd}]$ and $75 \%$ decrease in $[\mathrm{Cr}]$.

\section{Heavy Metal Concentration from different parts of the Fish}

The mean $\mathrm{Pb}$ concentration in the head part $(1.539 \pm 0.46$ $\mathrm{mg} \mathrm{kg}^{-1}$ ) was highest among the three parts followed by the muscle $\left(1.254 \pm 0.47 \mathrm{mg} \mathrm{kg}^{-1}\right)$ and stomach $(1.018 \pm 0.31$ $\mathrm{mg} \mathrm{kg} \mathrm{k}^{-1}$ ) in both fish samples (Figure 3). The statistical comparison showed that the mean $[\mathrm{Pb}]$ from three parts were significantly different from each other $(\mathrm{p}<0.05)$.

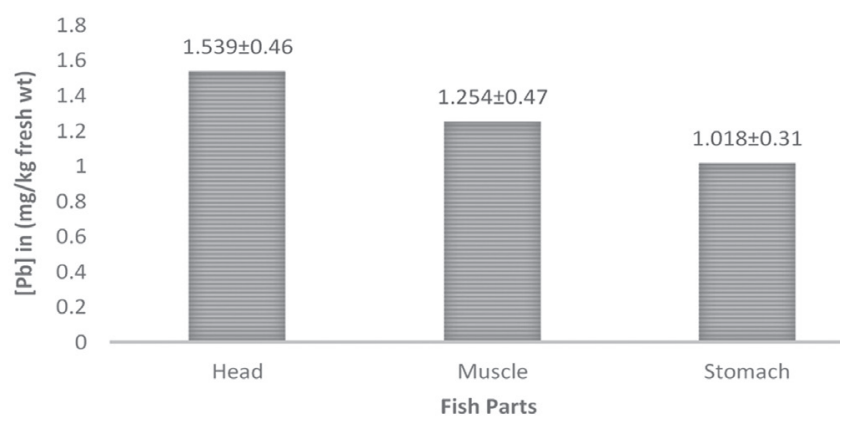

Figure 3. Mean Lead ( $\mathrm{Pb}$ ) concentration ( $\mathrm{mg} \mathrm{kg}^{-1}$, fresh weight) in the different fish parts.

Among the fish parts, the mean concentration of $\mathrm{Cd}$ was found highest in the head part $\left(0.161 \pm 0.08 \mathrm{mg} \mathrm{kg}^{-1}\right)$ followed by the muscle $\left(0.123 \pm 0.07 \mathrm{mg} \mathrm{kg}^{-1}\right)$ and stomach $\left(0.104 \pm 0.05 \mathrm{mg} \mathrm{kg}^{-1}\right)$ in both fish samples (Figure 4). Statistical comparisons show that the mean $\mathrm{Cd}$ concentration in the head part was significantly different from both muscle and stomach $(\mathrm{p}<0.05)$. Meanwhile, the mean concentration of $\mathrm{Cd}$ in the muscle and stomach was not significantly different $(p>0.05)$.

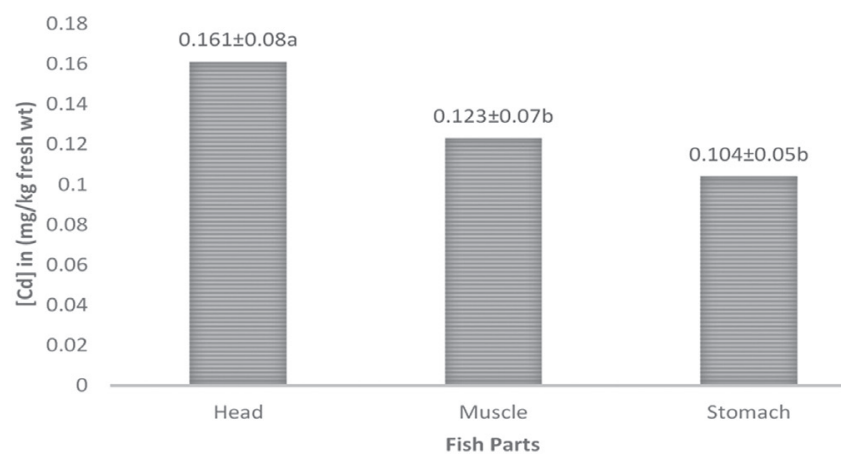

Figure 4. Mean Cadmium (Cd) concentration (mg kg-1, fresh weight) in the different fish parts.

$\mathrm{Cr}$ bioaccumulation pattern in the fish parts was the same observed from $\mathrm{Pb}$ and $\mathrm{Cd}$. The highest mean concentration of $\mathrm{Cr}$ was recorded in the head part $(0.057 \pm 0.02$ $\left.\mathrm{mg} \mathrm{kg}{ }^{-1}\right)$ followed by the muscle part $\left(0.043 \pm 0.02 \mathrm{mg} \mathrm{kg}^{-1}\right)$ and stomach $\left(0.033 \pm 0.01 \mathrm{mg} \mathrm{kg}^{-1}\right)$ (Figure 5). The statistical

Table 3. Means of Heavy Metal concentration ( $\mathrm{mg} \mathrm{kg}^{-1}$, fresh weight) in Raw and Boiled Nile and Blackchin Tilapia

\begin{tabular}{|c|c|c|c|c|c|c|}
\hline \multirow{2}{*}{ Treatment } & \multicolumn{2}{|c|}{ Lead $(\mathrm{Pb})$} & \multicolumn{2}{|c|}{ Cadmium (Cd) } & \multicolumn{2}{|c|}{ Chromium (Cr) } \\
\hline & Nile & Blackchin & Nile & Blackchin & Nile & Blackchin \\
\hline Raw & $1.16 \pm 0.58^{\mathrm{a}}$ & $1.38 \pm 0.29^{a}$ & $0.10 \pm 0.08^{a}$ & $0.15 \pm 0.05^{\mathrm{a}}$ & $0.05 \pm 0.02^{a}$ & $0.04 \pm 0.02^{\mathrm{a}}$ \\
\hline Boiled & $0.34 \pm 0.25^{b}$ & $0.43 \pm 0.37^{b}$ & $0.05 \pm 0.02^{b}$ & $0.07 \pm 0.03^{b}$ & $0.02 \pm 0.0^{\mathrm{b}}$ & $0.01 \pm 0.00^{b}$ \\
\hline
\end{tabular}

Values having the same superscript across a column are not significantly different at $P<0.05$ 


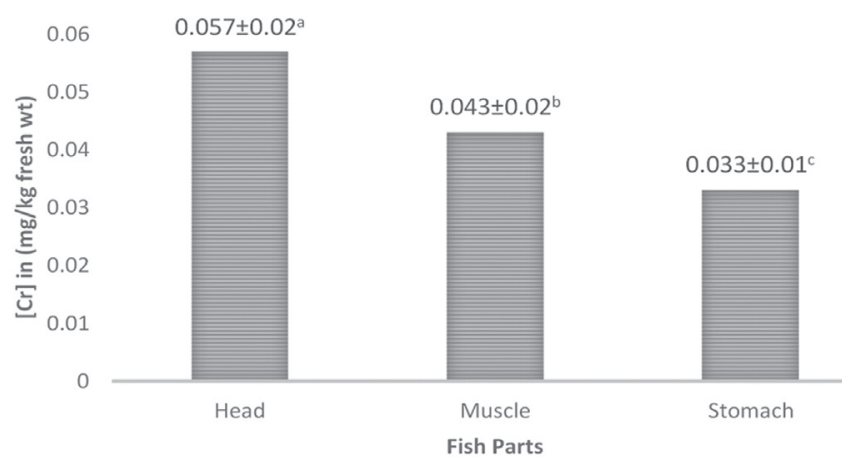

Figure 5. Mean Chromium ( $\mathrm{Cr}$ ) concentration (mg kg-1, fresh weight) in the different fish parts.

comparison revealed that the mean $[\mathrm{Cr}]$ from three parts were significantly different from each other $(p<0.05)$.

\section{Human Health Risk Assessment}

The estimated dietary intake (EDI) of metals based on per capita consumption of fish in the Philippines are shown in Table 4 The EDI of $\mathrm{Pb}$ from the consumption of raw Nile Tilapia ranged from $1.48 \mathrm{mg} \mathrm{kg}^{-1} \mathrm{bw} \mathrm{day}{ }^{-1}$ to 3.38 $\mathrm{mg} \mathrm{kg}{ }^{-1}$ bw day ${ }^{-1}$ with the highest $\mathrm{Pb}$ intake coming from Los Baños and lowest in Bay. In Blackchin Tilpia, EDI ranged from $2.11 \mathrm{mg} \mathrm{kg}^{-1} \mathrm{bw} \mathrm{day}^{-1}$ to $2.99 \mathrm{mg} \mathrm{kg}^{-1} \mathrm{bw} \mathrm{day}^{-1}$ with the highest intake coming from Calamba and lowest in Bay. Higher EDIs of $\mathrm{Pb}$ in both fish species were recorded in females compared to males. Essentially, lower EDI was obtained from boiled fish compared to raw since the previous result showed that there was a significant decrease in $\mathrm{Pb}$ concentration in the fish tissues when boiled. The EDI of $\mathrm{Pb}$ for boiled Nile Tilapia ranged from $0.21 \mathrm{mg} \mathrm{kg}^{-1}$ bw day ${ }^{-1}$ to $0.91 \mathrm{mg} \mathrm{kg}^{-1}$ bw day ${ }^{-1}$ while the EDI for boiled Blackchin Tilapia ranged from $0.21 \mathrm{mg} \mathrm{kg}^{-1}$ bw day ${ }^{-1}$ to $1.15 \mathrm{mg} \mathrm{kg}^{-1}$ bw day ${ }^{-1}$. All EDI of $\mathrm{Pb}$, except from the consumption of boiled Blackchin Tilapia in Bay, exceeded the WHO/FAO maximum tolerable concentration (MTC) of 0.30 and indicates potential health risks to consumers. ${ }^{13,16}$

For the estimated daily intake (EDI) of Cd, all, except from the consumption of boiled Nile Tilapia in Los Baños, exceeded WHO/FAO maximum permissible limit of 0.05 . This implies a potential adverse non-carcinogenic health risk to consumers. Regardless of the location, the EDIs ranged from $0.10 \mathrm{mg} \mathrm{kg}^{-1}$ bw day ${ }^{-1}$ to $0.31 \mathrm{mg} \mathrm{kg}^{-1} \mathrm{bw} \mathrm{day}{ }^{-1}$ for raw Nile Tilapia while $0.22 \mathrm{mg} \mathrm{kg}^{-1}$ bw day-1 to $0.38 \mathrm{mg} \mathrm{kg}^{-1} \mathrm{bw}$ $\mathrm{day}^{-1}$ for raw Blackchin Tilapia. The Highest EDI of Cd was recorded in Los Baños. Similar to $\mathrm{Pb}$, EDIs of $\mathrm{Cd}$ for boiled samples were lower compared to raw. EDIs ranged from $0.03 \mathrm{mg} \mathrm{kg}^{-1}$ bw day ${ }^{-1}$ to $0.11 \mathrm{mg} \mathrm{kg}^{-1}$ bw day ${ }^{-1}$ in boiled Nile Tilapia and $0.10 \mathrm{mg} \mathrm{kg}^{-1} \mathrm{bw}$ day $^{-1}$ to $0.17 \mathrm{mg} \mathrm{kg}^{-1} \mathrm{bw} \mathrm{day}^{-1}$ in boiled Blackchin Tilapia.

Among the heavy metals studied, $\mathrm{Cr}$ concentration was found to have the lowest EDI in both fish samples. Results showed that none of the EDIs exceeded the maximum tolerable concentration of $1 \mathrm{mg} \mathrm{kg}^{-1} \mathrm{bw}$ day $^{-1} .{ }^{16}$ The EDI of $\mathrm{Cr}$ for raw Nile Tilapia and Blackchin Tilapia ranged from $0.077 \mathrm{mg} \mathrm{kg}^{-1}$ bw day ${ }^{-1}$ to $0.096 \mathrm{mg} \mathrm{kg}^{-1} \mathrm{bw}$ day $^{-1}$ and 0.053 $\mathrm{mg} \mathrm{kg}{ }^{-1}$ bw day ${ }^{-1}$ to $0.104 \mathrm{mg} \mathrm{kg}^{-1}$ bw day ${ }^{-1}$ respectively. For boiled Nile and Blackchin Tilapia, EDI of $\mathrm{Cr}$ ranged from $0.024 \mathrm{mg} \mathrm{kg}^{-1}$ bw day ${ }^{-1}$ to $0.036 \mathrm{mg} \mathrm{kg}^{-1} \mathrm{bw} \mathrm{day}^{-1}$ and 0.021 $\mathrm{mg} \mathrm{kg}{ }^{-1}$ bw day ${ }^{-1}$ to $0.027 \mathrm{mg} \mathrm{kg}^{-1}$ bw day ${ }^{-1}$ respectively. Highest EDI was recorded in Los Baños. Similar to $\mathrm{Pb}$ and $\mathrm{Cd}$, lower EDI of $\mathrm{Cr}$ was obtained from the consumption of boiled samples compared to raw.

Table 5 provided information on the total hazard quotient (THQ) of metals from the consumption of these fish species. These parameters were introduced by the Environmental Protection Agency (EPA) in the United States for the estimation of potential health risks caused by any chemical contaminant over prolonged exposure. ${ }^{17}$

Table 4. Estimated dietary intake (EDI) of heavy metals in raw and boiled samples collected from different locations

\begin{tabular}{|c|c|c|c|c|c|c|c|c|}
\hline \multirow{3}{*}{ Location } & \multirow{3}{*}{ Specie } & \multirow{3}{*}{ Treatment } & \multicolumn{6}{|c|}{ EDI (mg kg-1 bw day-1) } \\
\hline & & & \multicolumn{2}{|c|}{$\mathrm{Pb}$} & \multicolumn{2}{|c|}{$\mathrm{Cd}$} & \multicolumn{2}{|c|}{$\mathrm{Cr}$} \\
\hline & & & Male & Female & Male & Female & Male & Female \\
\hline \multirow[t]{4}{*}{ Los Baños } & Nile Tilapia & Raw & $2.94^{*}$ & $3.38^{*}$ & $0.27^{*}$ & $0.31^{*}$ & 0.083 & 0.096 \\
\hline & & Boiled & $0.71^{*}$ & $0.81^{*}$ & 0.03 & 0.03 & 0.031 & 0.036 \\
\hline & Blackchin Tilapia & Raw & $2.32^{*}$ & $2.67^{*}$ & $0.33^{*}$ & $0.38^{*}$ & 0.091 & 0.104 \\
\hline & & Boiled & $1.00^{*}$ & $1.15^{*}$ & $0.10^{*}$ & $0.12^{*}$ & 0.023 & 0.026 \\
\hline \multirow[t]{4}{*}{ Calamba } & Nile Tilapia & Raw & $1.48^{*}$ & $1.70^{*}$ & $0.16^{*}$ & $0.19^{*}$ & 0.077 & 0.089 \\
\hline & & Boiled & $0.79^{*}$ & $0.91^{*}$ & $0.10^{*}$ & $0.11^{*}$ & 0.025 & 0.029 \\
\hline & Blackchin Tilapia & Raw & $2.59^{*}$ & $2.99^{*}$ & $0.24^{*}$ & $0.28^{*}$ & 0.066 & 0.076 \\
\hline & & Boiled & $0.98^{*}$ & $1.13^{*}$ & $0.11^{*}$ & $0.12^{*}$ & 0.021 & 0.024 \\
\hline \multirow[t]{4}{*}{ Bay } & Nile Tilapia & Raw & $1.51^{*}$ & $1.74^{*}$ & $0.10^{*}$ & $0.12^{*}$ & 0.079 & 0.091 \\
\hline & & Boiled & $0.21^{*}$ & $0.24^{*}$ & $0.08^{*}$ & $0.09^{*}$ & 0.024 & 0.027 \\
\hline & Blackchin Tilapia & Raw & $2.11^{*}$ & $2.43^{*}$ & $0.22^{*}$ & $0.25^{*}$ & 0.053 & 0.061 \\
\hline & & Boiled & 0.21 & 0.24 & $0.15^{*}$ & $0.17^{*}$ & 0.024 & 0.027 \\
\hline \multicolumn{3}{|c|}{ Maximum Permissible Limit } & \multicolumn{2}{|c|}{$0.30 \mathrm{mg} / \mathrm{kg}^{\mathrm{a}}$} & \multicolumn{2}{|c|}{$0.05 \mathrm{mg} / \mathrm{kg}^{\mathrm{a}}$} & \multicolumn{2}{|c|}{$1 \mathrm{mg} / \mathrm{kg}^{\mathrm{b}}$} \\
\hline
\end{tabular}

*Values that exceeded the Maximum Permissible Limit

${ }^{a} \mathrm{FAO} / \mathrm{WHO}$ (2011), ${ }^{b} \mathrm{FAO} / \mathrm{WHO}$ (2002) 
Health Risk Assessment of Heavy Metals in Selected Fish Species from South Bay of Laguna Lake

Table 5. Total Hazard Quotient (THQ) and Hazard Index (HI) for different heavy metals of two fish species collected from different locations at South Bay of Laguna Lake

\begin{tabular}{|c|c|c|c|c|c|c|c|c|c|c|c|}
\hline \multirow{3}{*}{ Location } & \multirow{3}{*}{ Specie } & \multirow{3}{*}{ Treatment } & \multicolumn{9}{|c|}{ THQ } \\
\hline & & & \multicolumn{3}{|c|}{$\mathrm{Pb}$} & \multicolumn{3}{|c|}{$\mathrm{Cd}$} & \multicolumn{3}{|c|}{$\mathrm{Cr}$} \\
\hline & & & Male & Female & Ave & Male & Female & Ave & Male & Female & Ave \\
\hline \multirow[t]{4}{*}{ Los Baños } & Nile Tilapia & Raw & 0.33 & 0.38 & 0.36 & $1.21^{*}$ & $1.39 *$ & $1.30^{*}$ & 0.21 & 0.24 & 0.23 \\
\hline & & Boiled & 0.08 & 0.09 & 0.09 & 0.13 & 0.16 & 0.14 & 0.08 & 0.09 & 0.08 \\
\hline & Blackchin Tilapia & Raw & 0.26 & 0.30 & 0.28 & $1.51^{*}$ & $1.74^{*}$ & $1.63^{*}$ & 0.23 & 0.26 & 0.25 \\
\hline & & Boiled & 0.11 & 0.13 & 0.12 & 0.46 & 0.53 & 0.50 & 0.06 & 0.07 & 0.06 \\
\hline \multirow[t]{4}{*}{ Calamba } & Nile Tilapia & Raw & 0.17 & 0.19 & 0.18 & 0.74 & 0.86 & 0.80 & 0.19 & 0.22 & 0.21 \\
\hline & & Boiled & 0.09 & 0.10 & 0.10 & 0.44 & 0.51 & 0.48 & 0.06 & 0.07 & 0.07 \\
\hline & Blackchin Tilapia & Raw & 0.29 & 0.34 & 0.32 & $1.09^{*}$ & $1.25^{*}$ & $1.17^{*}$ & 0.17 & 0.19 & 0.18 \\
\hline & & Boiled & 0.11 & 0.13 & 0.12 & 0.49 & 0.56 & 0.52 & 0.05 & 0.06 & 0.06 \\
\hline \multirow[t]{4}{*}{ Bay } & Nile Tilapia & Raw & 0.17 & 0.20 & 0.18 & 0.46 & 0.53 & 0.50 & 0.20 & 0.23 & 0.21 \\
\hline & & Boiled & 0.02 & 0.03 & 0.03 & 0.36 & 0.41 & 0.39 & 0.06 & 0.07 & 0.06 \\
\hline & Blackchin Tilapia & Raw & 0.24 & 0.28 & 0.26 & 0.98 & $1.12^{*}$ & $1.05^{*}$ & 0.13 & 0.15 & 0.14 \\
\hline & & Boiled & 0.02 & 0.03 & 0.03 & 0.68 & 0.78 & 0.73 & 0.06 & 0.07 & 0.06 \\
\hline
\end{tabular}

*Values are higher than the recommended limit (THQ $\geq 1.0)$

For $\mathrm{Pb}$, all THQ value was less than 1.0. The highest average THQ for male and female were estimated in raw Nile Tilapia from Los Baños with a score of only 0.36 . Hence, adverse non-carcinogenic risks for $\mathrm{Pb}$ consumption in the samples were not demonstrated in the present study. THQ value for $\mathrm{Cd}$ was recorded highest in raw Blackchin Tilapia and Nile Tilapia present also from Los Baños with scores 1.63 and 1.30 respectively. The scores were relatively higher than the recommended level of exposure (THQ $\geq$ 1.00). Thus, daily exposure at this level could likely cause an adverse health effect. Average THQ for Chromium, on the other hand, scored highest again in Los Baños for both species. However, all values did not exceed the recommended threshold of 1.0 thus the risk for the noncarcinogenic effect of $\mathrm{Cr}$ is low. Moreover, the THQvalues for all concerned heavy metals were comparatively higher in females than in males. This is probably due to the difference in the average weight.

\section{DISCUSSION}

There were several studies conducted to assess the heavy metal contamination in aquatic animals collected from different sampling zones in Laguna Lake. In the study conducted by de la Cruz et. al. (2016), Asian clams collected from different sampling zones in Laguna Lake showed detectable levels of $\mathrm{Pb}$ in soft tissue samples. Similar to the present study, the $[\mathrm{Pb}]$ showed higher concentrations detected in samples obtained from sites adjacent to the urban areas, Los Baños and Calamba, compared to samples collected from collection sites facing the rural towns of Bay, Victoria, and Kalayaan. Growing cities surfaced with factories and industrial parks that high concentrations of heavy metals dumped in the lake have become a major water quality problem. ${ }^{18}$
The concentration level in the head part of the fish could be attributed to the fact that water always passes through the mouth and gills when filtered. Bervoets et al. (2001) reported that more concentration of heavy metals accumulates in the gill than the liver followed by muscle and gut region for short time exposure. ${ }^{19}$ Varying levels of metal bioaccumulation in different parts of fish are attributed to the differences in their physiological function. Fish regulate metal ions through excretion via kidney and gills, however, such capacity of tissue is directly related to the total amount of metals' accumulation in those specific tissues. ${ }^{20}$

Several studies have indicated an increase in heavy metal concentration in foods using different cooking methods. According to the results of study conducted by Gheisari et. al (2016) on the effect of different cooking methods on lead and cadmium contents of shrimp and lobster, the concentrations of lead $(\mathrm{Pb})$ increased in fried samples showing significant differences when compared with steamed and boiled shrimp and boiled lobster $(\mathrm{P}<0.05) .{ }^{21}$ Moreover, investigations of Ersoy et al. (2006) on lead (Pb) and cadmium (Cd) concentrations in sea bass under four treatments also showed that lead $(\mathrm{Pb})$ concentrations in the baked and microwaved fish were significantly decreased. ${ }^{22}$ Although the reasons behind such differences are not quite clear, many factors such as the initial concentration of heavy metals in the meat, aquatic species, can affect the reduction or increase of these elements in the flesh as the result of cooking processes. ${ }^{21}$

Results of the risk assessment for the present study show that cadmium is of greater concern in terms of possible adverse health effects associated with heavy metal bioaccumulation. However, the presence of other heavy metals in fish species should not be deserted. Although there are limitations in establishing the risk for multiple exposures, it must be noted that various chemical exposure can also lead to increased health risk. 
Studies suggest that excess levels of this chemical may pose serious health problems in humans. Lead can cause effects on the blood, as well as the nervous, immune, renal and cardiovascular systems. Early childhood and prenatal exposures are associated with slowed cognitive development, learning deficits and other effects. Exposure to high amounts of lead can cause gastrointestinal symptoms, severely damage the brain and kidneys, and may cause reproductive effects. Large doses of some lead compounds have caused cancer in lab animals. ${ }^{23}$ On the other hand, the kidney is the critical target organ in humans for cadmium toxicity. Cadmium accumulates primarily in the kidneys, and its biological halflife in humans is $10-35$ years. This accumulation may lead to renal tubular dysfunction and can lead to disturbances in calcium metabolism and the formation of kidney stones. Softening of the bones and osteoporosis may occur in those exposed through living or working in cadmiumcontaminated areas. ${ }^{24}$ According to USEPA, ingestion of high amounts of chromium causes gastrointestinal effects in humans and animals, including abdominal pain, vomiting, and hemorrhage. ${ }^{25}$

\section{CONCLUSION}

Results of the study showed that the average $[\mathrm{Pb}],[\mathrm{Cd}]$ and $[\mathrm{Cr}]$ were all recorded highest from fish samples obtained from Los Baños while lowest in Bay. Among the fish parts, the head part accumulated the highest concentration of all heavy metal followed by muscle and stomach. The heavy metal contents of all samples were significantly lower in boiled samples compared to raw samples. The difference ranged from $50 \%$ to $75 \%$ for all heavy metals in both species.

Estimated Daily Intake (EDI) of $\mathrm{Pb}$ from raw and boiled Blackchin Tilapia and Nile Tilapia, exceeded the maximum permissible limit except in boiled Blackchin Tilapia in Bay. Higher EDI of $\mathrm{Cd}$ was also recorded compared to the maximum permissible limit in most of the samples. Meanwhile, all computed EDI of $\mathrm{Cr}$ did not exceed its maximum permissible limit.

Adverse health effects associated with Nile Tilapia and Blackchin Tilapia consumption were demonstrated in this study. Among the three metals, THQ value for $\mathrm{Cd}$ was recorded highest in raw Blackchin Tilapia and Nile Tilapia collected from Los Baños. The scores for $\mathrm{Cd}$ were relatively higher than the recommended level of exposure (THQ $\geq 1.00$ ) which indicates risk for non-carcinogenic health effects. Total hazard Quotient for $\mathrm{Pb}$ and $\mathrm{Cr}$ did not exceed the recommended value (THQ $<1.0)$. Nevertheless, there is still a possibility of an increase in health risk if there is prolonged exposure to multiple chemicals such as heavy metals.

\section{Statement of Authorship}

All authors participated in data collection and analysis, and approved the final version submitted.

\section{Author Disclosure}

All authors declare no conflicts of interest.

\section{Funding Source}

No funding support.

\section{REFERENCES}

1. Laguna Lake Development Authority (LLDA). Existing Lake Uses [Internet]. na. [cited 2017 October]. Available from http://llda.gov.ph/ existing-lake-uses/.

2. Molina, V.B., Espaldon, M.V.O., Favier, M.F., Pacardo, E.P., and Rebancos, R.M. Bioaccumulation in Nile tilapia (Oreochromis niloticus) from Laguna de Bay, Philippines. Journal of Environmental Science and Management. 2011. 14(2): 28-35.

3. Maruyama, S. and Kato, H. Identification of Waters Incorporated in Laguna Lake, Republic of the Philippines, Based on Oxygen and Hydrogen Isotopic Ratios. Water. 2017. 9. doi:10.3390/w9050328

4. Gochfeld, M. Cases of mercury exposure, bioavailability, and absorption. Ecotoxicology and Environmental Safety. 2003. 56: 174-9. doi: 10.1016/S0147-6513(03)00060-5.

5. Kalay, M. and Canli, M. Elimination of essential $(\mathrm{Cu}$ and $\mathrm{Zn})$ and nonessential $(\mathrm{Cd}$ and $\mathrm{Pb})$ metals from tissue of a freshwater fish, Tilapia zilli. Turkish Journal of Zoology. 2000. 24: 429 - 436.

6. Sankar, T.V., Zynudheen, A.A., Anandan, R. and Viswanathan, N.P.G. Distribution of organochlorine pesticides and heavy metal residues in fish and shellfish from Calicut Region, Kerela, India. Chemosphere. 2006. 65:583-590.

7. Martin, S. and Griswold, W. Human Health Effects of Heavy Metals. Environmental Science and Technology. 2009.15: 1-6.

8. World Health Organization. Food Safety Risk Assessment [Internet]. 2016. [cited 2017 October]. Available from http://www.who.int/ foodsafety/micro/riskassessment/en/

9. Association of Official Analytical Chemists (AOAC). AOAC official methods of analysis. 15th ed. Association of Official Analytical Chemists, Arlington, Virginia. 2015. pp. 84-85.

10. Giri, S. and Singh, A.K. Human health risk and ecological risk assessment of metals in fishes, shrimps and sediment from a tropical river. International Journal of Environmental Science and Technology. 2015. 12: 2349-2362. doi: 10.1007/s13762-014-0600-5

11. Molina, V.B. Health risk assessment of heavy metals in Manila catfish (Arius dispar) from Laguna Lake. Acta Med Philipp. 2014. 48: 22-7. doi: $10.47895 /$ amp.v48i1.1183

12. Food and Nutrition Research Institute- Department of Science and Technology. Philippine Dietary Reference Intake. 2015. Available from http://www.fnri.dost.gov.ph/images/sources/PDRI-Tables.pdf

13. Zhuang, P., Zou, B., Li, N.Y. and Li, Z.A. Health risk assessment for consumption of fish originating from ponds near Dabaoshan mine, South China. Environ Geochem Health. 2013. 20(8):5844-54. doi: 10.1007/s11356-013-1606-0

14. Sarkar,T.Alam,M.Parvin,N. Fardous,Z., Chowdhury,A.,Hossain,M., Haque, M., and Biswas, N. Assessment of Heavy Metal Concentration and Human health risk in Shrimp collected from different farms and rivers at Khulna-Satkhira region. Bangladesh. Toxicology Reports. 2016. 3: 346-350. doi: 10.1016/j.toxrep.2016.03.003

15. Integrated Risk Information System. US Environmental Protection Agency [Internet]. 2011 [cited 2017 October]. Available from http://www.epa.gov/iris/help_gloss.htm

16. Islam,M.S.,Ahmed,M.K.,Habibullah-Al-Mamun,M., Raknuzzaman, M., Ali, M.M. and Eaton, D.W. Health risk assessment due to heavy metal exposure from commonly consumed fish and vegetables. Environ Syst Decis. 2016. 36:253. doi: 10.1007/s10669-016-9592-7.

17. Javed, M., and Usmani, N. Accumulation of heavy metals and human health risk assessment via the consumption of freshwater fish Mastacembelusarmatus inhabiting, thermal power plant effluent loaded canal. Springer Plus. 2016. 5 (1):776. doi: 10.1186/s40064016-2471-3 
18. De La Cruz, C.P., Lapie, L., Bunal, R., Catalma, M.N., and De Vera, N.M. Bioaccumulation And Health Risks Assessment Of Lead (Pb) In Asian Clams (Corbicula fluminea, MÜLLER) From Laguna De Bay, Philippines. Journal of Natural Sciences Research. 2017. 36(2): 366-372.

19. Bervoets, L., Blust, R. and Verheyen, R. Accumulation of metals in the tissues of three spined stickelback (Gasterosteus aculeatus) from natural fresh waters. Ecotoxicology and environmental safety. 2001. 48: 117-127. doi: 10.1006/eesa.2000.2010.

20. Kousar, S. and Javed, M. Heavy Metals Toxicity and Bioaccumulation Patterns in the Body Organs of Four Fresh Water Fish Species. Pakistan Veterinary Journal. 2014. 34: 161-164.

21. Gheisari, M., Raissy, M., and Rahimi, E. The Effect of Different Cooking Methods on Lead and Cadmium Contents of Shrimp and Lobster. Journal of Food Biosciences and Technology. 2016.2: 53-58

22. Ersoy, B., Yanar, Y., Kucukgulmez, A. and Celik, M. Effects of four cooking methods on the heavy metal concentrations of sea bass fillets (Dicentrarchus labrax Linne, 1785). Food Chemistry. 2005. 99: 748-751. doi: 10.1016/j.foodchem.2005.08.055.
23. United States Environmental Protection Agency (USEPA). USEPA Regional Screening Level (RSL) Summary Table: November 2011 [Internet] [cited 2017 October] Available from http://www.epa.gov/ regshwmd/risk/human/Index.htm

24. World Health Organization. Preventing Disease Through Healthy Environment Exposure to Cadmium: A Major Public Health Concern. Geneva, World Health Organization [Internet]. 2010. [cited 2017 October]. Available from http://www.who.int/ipcs/ features/cadmium.pdf

25. United States Environmental Protection Agency (USEPA). RiskBased Concentration Table Environmental Protection Agency, Philadelphia PA, Washington DC, United States [Internet]. 2000. [cited 2017 October]. Available from http://www.epa.gov/spc/pdfs/ rchandbk.pdf

Have you read the current trends in Medical and Health Research in the Philippines?

\title{
Acta Medica Philippina The National Health Science Journal
}

\author{
Access Online: www.actamedicaphilippina.upm.edu.ph
}

